\title{
Going under to stay on top: \\ How much real exchange rate undervaluation is needed to boost growth in developing countries ${ }^{1}$ \\ Bajando para permanecer en la cima: \\ Cuánta subvaluación del tipo de cambio real se necesita para impulsar el crecimiento de las economías en desarrollo
}

\author{
Cecilia Bermúdez** \\ CARLOS DABÚs***
}

\begin{abstract}
This paper explores the real exchange rate (RER)-economic growth relationship for a wide sample of countries over the period 1960-2009. After removing influential observations, the system-GMM estimates suggest a positive link between an undervalued RER and growth in non-industrial countries, particularly in those with upper-middle and high income levels. In turn, RER volatility is found harmful for growth. These results holds when testing for asymmetric effects of RER misalignment: a real undervaluation boosts growth in non-industrial countries, while overvaluation seems to have no effects at any income level. Besides, the magnitude of the misalignment is also relevant: an undervalued RER of about $26 \%$ on average has a positive impact on growth.
\end{abstract}

Key words: Economic growth, real exchange rate, exchange rate volatility, non-industrial countries.

JEL Classification: $04, F 4$.

* We thank the editor of Estudios de Economía and an anonymous reviewer for valuable comments and suggestions on the original manuscript. All errors and ommisions are responsibility of the authors.

** IIESS-CONICET and Departamento de Economía, Universidad Nacional del Sur. Calle San Andrés s/n, Campus de Palihue, Ciudad de Bahía Blanca (8000), Provincia de Buenos Aires, Argentina. E-mail: cbermudez@uns.edu.ar

*** IIESS-CONICET and Departamento de Economía, Universidad Nacional del Sur. Calle San Andrés s/n, Campus de Palihue, Ciudad de Bahía Blanca (8000), Provincia de Buenos Aires, Argentina. E-mail: cdabus@ criba.edu.ar

Received: June, 2016. Accepted: August, 2017. 


\section{Resumen}

El trabajo explora la relación entre el tipo de cambio real (TCR) y el crecimiento económico para una amplia muestra de países durante el periodo 1960-2009. Luego de eliminar los valores influyentes, las estimaciones basadas en el GMM sistémico muestran que un TCR devaluado impulsa el crecimiento a largo plazo de las economías no industrializadas, particularmente en aquellas de ingreso medio-alto y alto. A su vez, se encuentra que la volatilidad del TCR tiene un impacto negativo en el crecimiento. Estos resultados se mantienen cuando se descarta la existencia de efectos asimétricos en el desalineamiento cambiario: mientras que la sobrevaluación no tiene efectos significativos para ningún nivel de ingreso, un TCR subvaluado impulsa el crecimiento en los países no industrializados. Además, la magnitud del desalineamiento también es relevante: el efecto de una devaluación es significativo y positivo cuando la devaluación del RER es en promedio del $26 \%$.

Palabras clave: Crecimiento económico, tipo de cambio real, volatilidad cambiaria, países no industrializados.

Clasificación JEL: O4, F4.

\section{INTRODUCTION}

The relationship between the real exchange rate (RER) and economic growth has been a major concern for researchers and economic policy makers, especially in developing countries, where this linkage has been found much stronger than that for industrial countries. There are several channels through which the RER can influence economic performance, and in particular RER misalignments. External and/or internal equilibriums can be disturbed by changes in price levels (internal and international), trade, investment and other key variables, but their changes are in turn provoked by movements in the RER with respect to an "equilibrium" level. This is the reason for the first empirical papers being focused on measuring RER misalignment and assessing its impact on growth. In spite of the difficulty in finding quality data for developing countries, evidence shows that RER misalignments conduct to a decrease in economic growth rates in these countries. In line with this argument, Ghura and Grennes (1993) present evidence that show a negative relationship between the RER misalignment and economic growth for 33 countries of the Sub-Saharan Africa. Further analyses find that the impact of RER on economic growth depends on its deviation with respect to an "equilibrium" level.

In that sense, in most cases investigations suggest that an undervalued RER tends to favor economic growth, while an overvalued RER is expected to hinder the development process.

Razin and Collins (1999), using a pooled sample of 93 developed and developing countries, find that RER overvaluation is negatively correlated with economic growth. Interestingly, their evidence also indicates the existence of asymmetries: the negative effect of overvaluation is stronger than the positive effect of undervaluation. Similarly, Aguirre and Calderon (2005), using a panel of 60 countries for the 1965-2003 period, find that RER overvaluations are 
negatively correlated with growth; asymmetry also emerges in their results: the estimated coefficients are, in absolute values, larger for the overvaluation than for undervaluation cases. In a similar line, Gala (2008) shows a negative relationship between GDP per capita growth and RER overvaluation in a panel of 58 developing countries for the 1960-1999 period, while Hausmann et al. (2005) conclude that RER devaluations are followed by episodes of high economic growth ${ }^{1}$.

More recent literature also presents evidence indicating that an undervalued RER helps to increase GDP growth, while an overvalued currency has the contrary effect. For example, Tarawalie (2010), De Vita and Kyaw (2011), Abida (2011), Benhima (2012), and Elbadawi et al. (2012), show that exchange rate undervaluation (overvaluation) encourages (reduces) economic growth. In turn, for developing countries Glüzman et al. (2012) also find that an undervalued RER fosters economic growth. The evidence indicates that the underlying channel of this result is the effect of RER on saving and investment. The argument is that a depreciated RER reduces real wages, which implies a wealth transfer from workers to capitalists, who have a higher propensity to save. This reallocation of resources enhances saving and investment, thus promoting growth. Moreover, a higher RER promotes the development of the tradable sector, which is more dynamic and has more externalities and technological spillovers that can lead the growth process (Eichengreen (2007), Rapetti et al. (2012)). Besides, a higher RER tends to relax the historical external constraint in these economies. In this line, Rodrik (2008) analyses a panel of 184 countries during the 1960-2004 period, and shows that undervaluation of the currency stimulates economic growth, especially in lower income countries. Similarly, using Rodrik's undervaluation index, Rapetti et al. (2012) find that the effect of a real undervaluation on economic growth is indeed larger and more robust in the case of developing countries, while the effect of a more undervalued RER on growth decreases (non-monotonically) with the level of per capita GDP.

However, the benefits of maintaining a high RER can turn into a double-edge sword, because it can ultimately result in a contraction of aggregate demand. First, because even if the Marshall-Lerner condition is fulfilled, a real devaluation could have a high pass-through to domestic prices due to higher import costs. This would lead firms to increase their margins by lowering real wages. If mean propensity to savings is now higher (because of the resource reallocation) and real wages are lower, consumption will fall, thus leading to an overall fall in aggregate demand. Second, a real devaluation could increase the indebtedness ratio of firms and governments with foreign currency denominated debt. If the response of exports to the change in relative prices is slow, a real devaluation will deteriorate the balance sheets of the agents (Diaz Alejandro, 1963; Lopez and Perrotini, 2006).

\footnotetext{
However, there is another position, which argues that any real exchange-rate misalignment from its fundamentals equilibrium will lower growth, regardless of whether is it over or undervalued (Berg and Miao (2010)).
} 
While that sequence describes a theoretical short-run situation, keeping an artificially undervalued RER for too long may have significant adverse consequences. Haddad and Pancaro (2010) present at least six reasons not to maintain a high RER in the long run. The most relevant with respect to economic growth are: 1) a permanently undervalued RER can constrain the autonomy of monetary policy, leaving it no longer free to achieve other targets; 2) an artificial undervaluation is akin to a subsidy for the tradable sector, paid by the consumers, who consequently have reduced their purchasing power.

In an analogous line of reasoning, some recent studies suggest that an appreciated RER could not be as harmful for growth as it has been reported. Usually, shocks that cause Dutch disease -capital inflows, export price booms, etc.- are associated with periods of good economic performance. In this sense, the resulting RER could be lower but it could be a new "equilibrium" exchange rate as a result of a change in the fundamentals. Therefore, a more appreciated RER should not be confused with an "overvalued" RER, especially when its link to growth is being evaluated (Magud and Sosa, 2011).

On the other hand, the second channel through which RER can influence growth is its volatilty. There are studies suggesting that high real exchange rate volatilty reduces economic growth. In this sense, Cottani et al. (1990) state that large RER variations provoke greater uncertainty in relative prices, which in turn reduces investment horizons. They present evidence for a sample of less developed countries indicating an inverse relation between higher RER instability and economic growth. Bleaney and Greenaway (2001) estimate the impact of the terms of trade volatility and real effective exchange rate on investment and growth, for a panel of 14 sub-Saharan African countries during the period 1980-1995. They find that economic growth is negatively affected by terms of trade instability, while RER volatilty is harmful for investment (and then for economic growth). More recently, Janus and Riera-Crichton (2015), as well as Tarawalie (2010) and Vieira et al. (2013), find that RER volatility is negatively associated with growth. Finally, Rapetti et al. (2012) also report a negative link between RER volatility and long-term growth.

In short, the empirical literature seems to indicate that more competitive and less volatile RER foster growth processes, in particular in developing countries $^{2}$. In general previous works focus on assessing the differential impact of undervaluation on growth by testing for the presence of asymmetric effects (between over and undervaluation) or by empirically verifying the differential effect of income levels. However, the literature does not address the effect of the different undervaluation levels on economic growth, which is a relevant matter in the economic policy debate. In order to fulfill this gap, this paper builds on the conclusions of this brand of the literature; in this sense, our contribution is

2 An exception is Tang (2015), who in an empirical study for China finds that RER depreciations have not benefited economic growth. In fact, his findings indicate that this was particularly fostered by the expansion of exports and inflow of foreign capital. 
to determine how much undervaluation is needed to boost economic growth in developing countries. To do this, we use the k-means clustering algorithm, and obtain an optimal and consistent number of clusters which account for three different levels of the undervaluation index: a group of "overvalued" observations, another one of "moderate undervalued" observations, and a third one of "high undervalued" observations. Then we run regressions on each one of the clusters to verify whether the economic performance changes at different levels of the undervaluation index. In line with the literature, our evidence indicates that a more undervalued RER impulse growth in non-industrial economies, in particular in upper-middle and high income countries. Nevertheless, the level of RER is not neutral: undervaluation boosts economic growth in non-industrial countries only when the real undervaluation is, on the average, about $26 \%$. In turn, overvaluations and large undervaluations are not statistically significant to explain economic growth, while RER volatility is found generally harmful for growth in developing as well as in OECD countries. The crucial implication of our findings is that the level of real undervaluation matters when following an export-led growth strategy in non-industrial countries.

In the next section we present an empirical analysis of the data with descriptive statistics; in turn, the econometric model and the estimation methodology are presented. Then we introduce the income classification and the cluster algorithm that are developed and used to split the sample. Section 3 presents and discusses the estimation results, and finally Section 4 concludes.

\section{EMpirical Analysis}

\subsection{Exploratory Data Analysis}

The sample consists of 166 countries out of the 167 of the world sample included in the Penn World Table version 8.1 of Feenstra et al. (2015) ${ }^{3}$. The panel spans from 1960 to 2009, and comprises 10 non-overlapping five-year sub-periods. Table 1 reports summary statistics for the key variables of interest: the growth rate of real per capita GDP (which is the dependent variable in the estimated models), the undervaluation index (employed by Rodrik, 2008 and Rapetti et al., 2012), the RER volatility and the standard control variables, which includes the share of government consumption, the external debt, the degree of trade openness, the inflation rate, the terms of trade and the ratio of gross domestic savings to GDP.

3 Taiwan was excluded because there are no official statistics for this country publicly available in the World Bank's World Development Indicators datasets, which is the other source of information used in this work. 
TABLE 1

SUMMARY STATISTICS

\begin{tabular}{|c|c|c|c|c|c|c|c|c|}
\hline \multirow{2}{*}{ Variables } & \multirow{2}{*}{$\mathrm{N}$} & \multirow{2}{*}{ Mean } & \multirow{2}{*}{$\begin{array}{l}\text { Std. } \\
\text { Dev. }\end{array}$} & \multicolumn{5}{|c|}{ Tukey Fences } \\
\hline & & & & Min & Q1 & Q2 & Q3 & Max \\
\hline Growth rate & 1,446 & 1.9 & 7.2 & -49.3 & -0.5 & 2.2 & 4.6 & 104.5 \\
\hline Undervaluation & 1,430 & 1.2 & 0.7 & -2.8 & 0.7 & 1.1 & 1.6 & 5.4 \\
\hline RER Volatility & 1,445 & -1.9 & 1.0 & -5.0 & -2.6 & -1.9 & -1.2 & 1.2 \\
\hline Initial GDP & 1,080 & 7.8 & 1.0 & 5.1 & 7.0 & 7.7 & 8.7 & 10.6 \\
\hline External Debt & 700 & 64.2 & 72.9 & 0.0 & 27.2 & 46.6 & 76.3 & 977.3 \\
\hline Government Spending & 1,275 & 15.5 & 6.1 & 0.0 & 11.0 & 14.7 & 18.7 & 54.4 \\
\hline Gross Domestic Savings & 1,226 & 17.9 & 16.3 & -122.2 & 9.5 & 18.9 & 26.0 & 82.8 \\
\hline Degree of Openness & 1,335 & 59.5 & 49.1 & 6.4 & 32.6 & 48.6 & 74.2 & 834.0 \\
\hline Inflation & 1,195 & 2.2 & 1.2 & -3.8 & 1.4 & 2.1 & 2.6 & 9.1 \\
\hline Terms of Trade & 464 & 22.8 & 4.4 & -12.0 & 21.1 & 23.0 & 24.9 & 32.6 \\
\hline
\end{tabular}

Table 2 displays the minimum and maximum values of the variables of interest along with the limits to determine outliers using the quartile rule or "Tukey fences". A first pass at the data suggests that there are some outliers in the variables. Therefore, in Appendix 2 we present a careful examination of the data and a method for dealing with the possible outliers.

TABLE 2

TUKEY FENCES

\begin{tabular}{|lcc|}
\hline \multirow{2}{*}{ Variables } & \multicolumn{2}{c|}{ Tukey Fences $^{4}$} \\
\cline { 2 - 3 } & Lower Limit & Upper Limit \\
\hline Growth rate & -8.15 & 12.25 \\
Undervaluation & -0.53 & 2.80 \\
RER Volatility & -4.60 & 0.81 \\
\hline
\end{tabular}

\subsection{Econometric model}

Following Rodrik (2008), we use the PPP-based index of RER undervaluation, which consists of dividing the "verified" real exchange rate (calculated as the exchange rate divided by the PPP conversion factor) by the RER adjusted by the Balassa-Samuelson effect, which allows to take into account that the PPP is calculated over the entire GDP, including the non-tradeable goods. Thus,

4 The lower limit of the Tukey fences is determined by Q1-1.5*IQR. The upper limit is determined by $\mathrm{Q} 3+1.5 * \mathrm{IQR}$. The Interquartile Range (IQR) is the difference between Q3 and Q1. 
when taking natural logarithms of the variables, the undervaluation index can be written as:

$$
{\ln \_ \text {underval }_{i t}}=\ln _{-} R E R_{i t}-\ln _{-} R E R_{\text {Balassa-Samuelson }}{ }_{i t}
$$

Defined in this way, when the index exceeds unity, this indicates that the RER level is such that the currency is undervalued, and when it is below unity, the currency is overvalued.

We conduct growth regressions for a panel of 166 countries using ten nonoverlapping five-year sub-periods from the 1960-2009 period. The estimated model is:

$$
\text { Growth }_{i t}=\alpha+\beta G r o w t h_{i t-1}+\delta \ln _{-} \text {underval }_{i t}+\gamma V o l_{-} R E R_{i t}+\sigma x_{i t}+\eta_{i}+\varepsilon_{i t}
$$

where Growth $_{i t}$ is the average growth rate of real per capita GDP in each five-year period; Growth it-1 $_{\text {is }}$ the initial GDP growth rate calculated for each five-year period; In_underval ${ }_{i t}$ is the natural logarithm of the undervaluation index; Vol_RER is the volatility of the real exchange rate. In turn, $\chi_{i t}$ is a vector of the control variables mentioned above, $\eta_{i}$ account for the time-effect and $\varepsilon_{i t}$ is error term. Table 3 reports a description and the sources of each variable used in the estimations.

TABLE 3

\begin{tabular}{|c|c|c|c|}
\hline Code & Name & Description & Source \\
\hline GROWTH & $\begin{array}{l}\text { Real GDP per capita } \\
\text { growth rate }\end{array}$ & $\begin{array}{l}{\left[\left(\ln \_ \text {Real_GDPpc(t) - }\right.\right.} \\
\text { ln_Real_GDPpc }(\mathrm{t}-1)] / 5\end{array}$ & Authors' calculations \\
\hline UNDERVAL & Undervaluation index & $\begin{array}{l}1 / \text { [Price level of GDP } \\
\text { (chained PPP)] }\end{array}$ & $\begin{array}{l}\text { Authors' calculations } \\
\text { based on PWT } 8.1\end{array}$ \\
\hline VOL_RER & RER volatility & $\begin{array}{l}\text { Coefficient of variation } \\
\text { of RER within each } \\
5 \text {-year period }\end{array}$ & $\begin{array}{l}\text { Authors' calculations } \\
\text { based on PWT } 8.1\end{array}$ \\
\hline INITIAL_GDP & Initial GDP & $\begin{array}{l}\text { GDP at the beginning } \\
\text { of each 5-year period }\end{array}$ & $\begin{array}{l}\text { Authors' calculations } \\
\text { based on WDI }\end{array}$ \\
\hline EXT_DEBT & External Debt & $\begin{array}{l}\text { Total external debt stocks } \\
\text { to gross national income. }\end{array}$ & WDI \\
\hline GOV & $\begin{array}{l}\text { Government } \\
\text { Spending }\end{array}$ & $\begin{array}{l}\text { Government current } \\
\text { expenditures for purchases } \\
\text { of goods and services }\end{array}$ & WDI \\
\hline SAVINGS & $\begin{array}{l}\text { Gross Domestic } \\
\text { Savings }\end{array}$ & $\begin{array}{l}\text { GDP less final consumption } \\
\text { expenditure (total } \\
\text { consumption) }\end{array}$ & WDI \\
\hline OPEN & Degree of Openness & $\begin{array}{l}\text { Exports plus Imports } \\
\text { over GDP }\end{array}$ & WDI \\
\hline 1INFLA & $\begin{array}{l}\text { Logarithm of } \\
\text { inflation }\end{array}$ & $\begin{array}{l}\text { Log (1+annual rate } \\
\text { of inflation) }\end{array}$ & WDI \\
\hline TOT & Terms of Trade & $\begin{array}{l}\text { Capacity to import less } \\
\text { exports of goods and } \\
\text { services in constant prices }\end{array}$ & WDI \\
\hline
\end{tabular}

VARIABLES DEFINITION AND SOURCE 


\subsection{Income level classification}

In order to analyze whether there are differences in the economic growthRER relationship associated with income levels, we divided the sample into four categories. In this case, the use of the World Bank classification seems not appropriate, as countries are included into one or another income category according to their current degree of development. In our sample period, that covers 50 years, many of the countries that are now labeled as developed would not have been considered the same at the beginning of the sample, and vice versa.

Therefore, we used the income thresholds of the World Bank to develop our own country grouping, by using each year's threshold. The groupings we made are four: low and low-middle income countries ${ }^{5}$, upper-middle income countries, high-income countries, and high-income OECD members. A number was assigned to each category, starting from the first category with the number one. Then each observation is compared to the corresponding thresholds and matched to its corresponding income level. By taking into account the country and period (the five-years period in this case), we created a categorical variable of the income levels that has a "dynamic" character, and therefore allows countries to move from one level to another throughout the years.

\subsection{The uses of the undervaluation index}

The undervaluation index is firstly used to test for the presence of asymmetric effects of under and overvaluation. In the baseline equation, if the coefficient of undervaluation is positive and significant, it should mean that an undervalued RER has a positive link with growth, but it could also be reflecting the negative impact on growth of an overvaluation. In order to rule out this ambiguity, the baseline regression is carried out for observations associated to an undervalued and an overvalued RER, respectively, both for the full sample and also for the two subsamples of industrial and non-industrial countries.

Once the impact of undervaluation is unambiguously assessed, we tested for the magnitude effect, that is, for which levels the undervaluation index has a significant impact on growth. This can be achieved by creating groups of "similar" undervaluation index. The main problem is then finding a measure of that "similarity". In this work, we have decided to use the $k$-means algorithm (Hartigan, 1975). However, it is worthwhile noting that this clustering method is sensitive to the presence of outliers, which might cause the algorithm converge to a local optimum and substantially influence the final cluster result. As the outliers have been removed from the dataset, the clusters formed will contain observations that are truly "similar".

The k-means algorithm can be written as:

$$
\operatorname{argmin} \sum_{i=1}^{k} \sum_{x_{j} \in S_{i}}\left\|x_{j}-\mu_{i}\right\|
$$

5 Low and Low-Middle income are two separate categories in the World Bank classification, but we have joined them because there are not many low-income countries, and then we would have to discard this category when running the regressions. 
where $\mu$ represents the mean of each cluster ${ }^{6}$. The inner sum represents the sum of squares of the difference between observation $x$ in cluster $s$ and the mean of cluster $s$. Meanwhile, the outer sum indicates that the sums of all clusters from $i$ to $k$ are totaled to get a single number that will be minimized.

The algorithm is composed of the following steps:

1) Place $k$ points into the space represented by the objects that are being clustered. These points represent initial group centroids.

2) Assign each object to the group that has the closest centroid. In our work, we have chosen to work with the Euclidean distance.

3) When all objects have been assigned, recalculate the positions of the $k$ centroids.

4) Repeat steps 2 and 3 until the centroids no longer move. This produces a separation of the objects into groups from which the metric to be minimized can be calculated.

Following these steps, we built three clusters ${ }^{7}$ with a satisfactory number of observations, which allows us to run separate regressions. As it can be seen in Table 4, almost $70 \%$ percent of the observations are grouped under the "undervaluation" clusters. Moreover, approximately a half of the sample belongs to the "less undervalued" cluster, characterized by a $26 \%$ mean deviation from the "equilibrium" RER. Finally, the remaining $30 \%$ of the sample form a cluster of observations associated with a real overvaluation.

TABLE 4 DESCRIPTIVE STATISTICS OF LN_UNDERVAL BY CLUSTERS

\begin{tabular}{|lccccc|}
\hline \multicolumn{1}{|c}{ Cluster } & Obs & Mean & Std. Dev. & Min & Max \\
\hline High Undervaluation & 244 & 2.17 & 0.49 & 1.72 & 5.39 \\
Moderate Undervaluation & 684 & 1.26 & 0.23 & 0.88 & 1.72 \\
Overvaluation & 457 & 0.49 & 0.35 & -2.19 & 0.87 \\
\hline
\end{tabular}

In the following section the model specified in Section 2.2 is ran for the full sample, for the subsets of industrial and non-industrial countries and for each set of clusters.

$6 \quad$ We chose this method over hierarchical clustering techniques because the computational burden of analyzing 1660 observations and at least two variables is prohibitive.

7 In Appendix 1, we show how we obtained an optimal number of three clusters, by using the Calinsky-Harabasz rule. 


\section{EMpirical Results ${ }^{8}$}

\subsection{Econometric estimates by development status and income level}

In this section we present the empirical evidence on the economic growth-RER relationship. Table 5 shows the results of the baseline model estimates for the full sample and for industrial and non-industrial countries. The undervaluation index is significant and has a positive sign only for non-industrial countries. This result is in line with those reported in Rapetti et al. (2012) and Rodrik (2008), among others.

TABLE 5

FULL SAMPLE, INDUSTRIAL AND NON INDUSTRIAL COUNTRIES

\begin{tabular}{|lccc|}
\hline \multirow{1}{*}{ Variables } & $(1)$ & $(2)$ & $(3)$ \\
\cline { 2 - 4 } & All & Industrial & Non Industrial \\
\hline Growth ${ }_{\mathrm{i}, \mathrm{t}-1}$ & 0.0530 & 0.0757 & 0.0325 \\
In_underval & $(0.165)$ & $(0.630)$ & $(0.774)$ \\
& 1.036 & -0.165 & $\mathbf{2 . 2 0 7 * *}$ \\
In_volrer & $(0.151)$ & $(0.946)$ & $\mathbf{( 0 . 0 2 2 )}$ \\
& $-0.490^{* *}$ & 1.751 & $-0.626 * * *$ \\
ln_initial_GDP & $(0.014)$ & $(0.548)$ & $(0.008)$ \\
& -0.343 & $-1.592^{* * *}$ & $-0.843^{* *}$ \\
Constant & $(0.154)$ & $(0.0129)$ & $(0.0367)$ \\
& 2.499 & $22.28 * *$ & $5.496 * *$ \\
\hline Observations & $(0.102)$ & $(0.023)$ & $(0.041)$ \\
$\mathrm{N}^{\circ}$ of countries & 1,232 & 273 & 959 \\
$\mathrm{~N}^{\circ}$ of Instruments & 166 & 36 & 130 \\
AR1 Test (p-value) & 45 & 16 & 45 \\
AR2 Test (p-value) & 0.000 & 0.107 & 0.001 \\
Hansen Test (p-value) & 0.961 & 0.852 & 0.761 \\
& 0.207 & 0.179 & 0.398 \\
\hline
\end{tabular}

pval in parentheses.

$* * * \mathrm{p}<0.01, * * \mathrm{p}<0.05, * \mathrm{p}<0.1$

On the other hand, a usual practice in growth econometrics is to control for income levels, as it has been found that the degree of development can explain the significant differential impact on growth of certain key variables. Table 6 shows that the undervaluation index is positively related to income and development level; in fact, this index increases systematically with the income level.

8 The regressions where run with and without outliers. As shown in Section 2, the sample is polluted with several outlying observations which, if considered in the regressions, lead to spurious results. However, the results of the regressions including outliers are available upon request. 
These differences lead to the question of whether the growth - RER relationship is also differentially affected by the degree of development. In order to determine this, in Table 7 we present the estimation results of such relationship by income level. This shows that only for upper-middle and high income countries the undervaluation index is significant and has the expected (positive) sign to explain economic growth.

TABLE 6

SUMMARY STATISTICS FOR UNDERVALUATION INDEX (IN LOGARITHM) BY INCOME LEVEL

\begin{tabular}{|lccccc|}
\hline \multicolumn{1}{|c}{ Income Level } & Obs & Mean & Std. Dev. & Min & Max \\
\hline Low-Low Middle & 467 & 0.9 & 0.7 & -2.7 & 2.5 \\
Upper-Middle & 381 & 1.1 & 0.6 & -0.4 & 3.2 \\
High & 358 & 1.3 & 0.6 & -0.1 & 3.2 \\
High - OECD & 224 & 1.6 & 0.8 & -1.0 & 5.4 \\
\hline
\end{tabular}

Table 7 presents the results of the estimates by income level.

TABLE 7

REGRESSIONS BY DYNAMIC INCOME CLASSIFICATION

\begin{tabular}{|c|c|c|c|c|}
\hline & (1) & (2) & (3) & (4) \\
\hline Variables & $\begin{array}{l}\text { Low-Low Mid } \\
(281-2111)\end{array}$ & $\begin{array}{l}\text { Upper-Mid } \\
(2112-5792)\end{array}$ & $\begin{array}{c}\text { High } \\
(5793-15891)\end{array}$ & $\begin{array}{l}\text { High OECD } \\
(>15793)\end{array}$ \\
\hline Growth $_{\mathrm{i}, \mathrm{t}-1}$ & $\begin{array}{c}0.103 \\
(0.266)\end{array}$ & $\begin{array}{l}0.412 * * * \\
(0.000)\end{array}$ & $\begin{array}{r}0.0201 \\
(0.583)\end{array}$ & $\begin{array}{l}-0.271 \\
(0.297)\end{array}$ \\
\hline ln_underval & $\begin{array}{c}0.566 \\
(0.419)\end{array}$ & $\begin{array}{l}2.637 * * \\
(0.012)\end{array}$ & $\begin{array}{l}2.060 * * \\
(0.048)\end{array}$ & $\begin{array}{c}1.851 \\
(0.549)\end{array}$ \\
\hline ln_volrer & $\begin{array}{l}-0.429 \\
(0.153)\end{array}$ & $\begin{array}{c}-0.562 * \\
(0.068)\end{array}$ & $\begin{array}{l}-0.307 \\
(0.516)\end{array}$ & $\begin{array}{l}-8.895 * * * \\
(0.000)\end{array}$ \\
\hline ln_initial_GDP & $\begin{array}{l}-0.877 * * \\
(0.019)\end{array}$ & $\begin{array}{l}-3.579 * * * \\
(0.000)\end{array}$ & $\begin{array}{l}-2.447 * * * \\
(0.000)\end{array}$ & $\begin{array}{l}-8.121 * * \\
(0.038)\end{array}$ \\
\hline Constant & $\begin{array}{l}6.641 * * * \\
(0.007)\end{array}$ & $\begin{array}{l}27.95^{* * * *} \\
(0.000)\end{array}$ & $\begin{array}{l}22.25 * * * \\
(0.000)\end{array}$ & $\begin{array}{l}54.14 \\
(0.111)\end{array}$ \\
\hline Observations & 385 & 326 & 312 & 209 \\
\hline $\mathrm{N}^{\circ}$ of countries & 67 & 88 & 88 & 48 \\
\hline $\mathrm{N}^{\circ}$ of Instruments & 52 & 51 & 47 & 16 \\
\hline AR1 Test (p-value) & 0.0163 & 0.001 & 0.002 & 0.024 \\
\hline AR2 Test (p-value) & 0.525 & 0.675 & 0.494 & 0.600 \\
\hline Hansen Test (p-value) & 0.592 & 0.939 & 0.308 & 0.762 \\
\hline
\end{tabular}

pval in parentheses

$* * * \mathrm{p}<0.01, * * \mathrm{p}<0.05, * \mathrm{p}<0.1$. 
The significance in the main parameters of the subsample of non-industrial countries is due to the results found for these two income level categories. It is worthwhile noting that the set of non-industrial countries is a rather static and large group of countries, while the income levels classification is more accurate and has a dynamic character derived from its construction, as it was explained above. Throughout the 50-years span of our analysis, countries have moved from one level to another, mostly in an upward direction. This is specially the case of many countries that in the 1960s were classified as low or low-middle income and in the upcoming years rapidly moved to the next higher income level, leaving those categories with fewer observations, which is the reason for they been group together. Also, the upper-middle and high income categories that are relevant to our analysis include countries that have had periods of high and sustained growth rates, and therefore have been able to move up to higher income levels. In particular, this is the case of several East Asian, South American and several transitional developing economies (Eichengreen (2008)).

In turn, the use of a dynamic income classification allows us to avoid ad hoc criteria to divide the sample. In this sense, our evidence is partially compatible with that reported in Rapetti et al. (2012) and Rodrik (2008), as we fail to find a significant relation between growth and RER in the lower income categories. However, our results coincide with those papers for the case of middle and high income level countries. A plausible explanation for these findings is rehearsed by Rapetti et al. (2012) through the "bottle neck effect": in less developed countries, acceleration of growth and capital accumulation have a negative impact on the balance of payment, because of the great dependence on imported capital goods. Therefore, according to this reasoning, a higher level of RER tends to diminish this restriction and boost growth. While this intuition might be right, we should add, in light of our results, that in order to take advantage of the potential benefits of a real undervaluation, countries must have surpassed a certain "income threshold", as the negative effects of a devaluation on real wages could compensate its positive impacts through the investment and/or the external channels, thus having no significant effects on long term growth.

\subsection{Asymmetric effects of RER misalignment}

Due to the use of the variable "undervaluation" as an index, the previous results could be reflecting the negative effect of overvaluation on growth, instead of the net positive effect of undervaluation. In order to rule out the existence of asymmetric effects, we carry out regressions on the two possible ranges of values of the (logarithm of the) undervaluation index: above (overvaluation) and below (undervaluation) the unity ${ }^{9}$.

$9 \quad$ There are no values of (the logarithm of) undervaluation that are exactly equal to one when using up to the third decimal. 
Table 8 reports the results of the baseline equation estimates in each scenario, for the full sample and for the subsamples of industrial and nonindustrial countries.

TABLE 8

ASYMMETRIC EFFECTS OF RER MISALIGNMENT

\begin{tabular}{|c|c|c|c|c|c|c|}
\hline \multirow{3}{*}{ Variables } & \multicolumn{2}{|c|}{ Full Sample } & \multicolumn{2}{|c|}{ Industrial } & \multicolumn{2}{|c|}{ Non Industrial } \\
\hline & (1) & (2) & (3) & (4) & (5) & (6) \\
\hline & Overvalued & Undervalued & Overvalued & Undervalued & Overvalued & Undervalued \\
\hline Growth i,t-1 & $\begin{array}{c}0.145 \\
(0.265)\end{array}$ & $\begin{array}{l}0.464 * * * \\
(0.008)\end{array}$ & $\begin{array}{r}-0.0269 \\
(0.563)\end{array}$ & $\begin{array}{c}0.0212 \\
(0.660)\end{array}$ & $\begin{array}{c}0.0232 \\
(0.396)\end{array}$ & $\begin{array}{l}0.376^{* * * *} \\
(0.009)\end{array}$ \\
\hline ln_underval & $\begin{array}{c}0.592 \\
(0.629)\end{array}$ & $\begin{array}{l}2.587 * * * \\
(0.001)\end{array}$ & $\begin{array}{l}-3.405 \\
(0.402)\end{array}$ & $\begin{array}{c}1.979 \\
(0.193)\end{array}$ & $\begin{array}{l}-0.141 \\
(0.939)\end{array}$ & $\begin{array}{c}3.008 * * \\
(0.039)\end{array}$ \\
\hline ln_volrer & $\begin{array}{l}-0.362 \\
(0.229)\end{array}$ & $\begin{array}{l}-0.478 \\
(0.151)\end{array}$ & $\begin{array}{c}1.497 \\
(0.187)\end{array}$ & $\begin{array}{c}-0.179 \\
(0.531)\end{array}$ & $\begin{array}{c}-0.644 * * \\
(0.0340)\end{array}$ & $\begin{array}{l}-0.960 * * \\
(0.010)\end{array}$ \\
\hline ln_initial & $\begin{array}{l}-0.031 \\
(0.930)\end{array}$ & $\begin{array}{l}-1.099 * * * \\
(0.001)\end{array}$ & $\begin{array}{c}-1.699^{*} \\
(0.052)\end{array}$ & $\begin{array}{l}-2.136^{* * * *} \\
(0.000)\end{array}$ & $\begin{array}{c}-0.0288 \\
(0.940)\end{array}$ & $\begin{array}{l}-1.896^{* * * *} \\
(0.000)\end{array}$ \\
\hline Constant & $\begin{array}{c}0.858 \\
(0.724)\end{array}$ & $\begin{array}{c}5.636^{* * *} \\
(0.014)\end{array}$ & $\begin{array}{l}25.57^{*} \\
(0.053)\end{array}$ & $\begin{array}{l}19.04 * * * \\
(0.000)\end{array}$ & $\begin{array}{c}0.598 \\
(0.795)\end{array}$ & $\begin{array}{l}11.01 * * * \\
(0.002)\end{array}$ \\
\hline Observations & 549 & 683 & 47 & 226 & 502 & 457 \\
\hline $\mathrm{N}^{\mathrm{o}}$ of countries & 132 & 159 & 22 & 36 & 110 & 123 \\
\hline $\mathrm{N}^{\circ}$ of Instruments & 39 & 27 & 16 & 16 & 18 & 20 \\
\hline AR1 Test (p-value) & 0.001 & 0.001 & 0.066 & 0.134 & 0.000 & 0.002 \\
\hline AR2 Test (p-value) & 0.783 & 0.211 & 0.684 & 0.758 & 0.624 & 0.461 \\
\hline Hansen Test (p-value) & 0.541 & 0.540 & 0.677 & 0.744 & 0.569 & 0.316 \\
\hline
\end{tabular}

pval in parentheses.

$* * * \mathrm{p}<0.01, * * \mathrm{p}<0.05, * \mathrm{p}<0.1$

The undervaluation index is positive and significant to explain growth only in the case of real undervaluation, for the full sample and for non-industrial countries. On the other side, overvaluation has no statistical effect on growth, regardless of the development status of the countries. These results are partially compatible with the literature, because while we find that a real undervaluation can improve the economic performance of non-industrial countries, we do not find the damaging effects of overvaluation that has been a constant in the literature of the last twenty years (Fischer, 1993, Easterly, 2005 and Rodrik, 2008). However, it is worth noting that for industrial countries the lack of significance in the coefficients is likely attributable to the small number of observations available for each range of the undervaluation index, thus limiting the confidence on the results. On the other hand, the results for non-industrial countries indicate that 
while undervaluation might exert growth in the long run, there is not statistical evidence on real overvaluation.

\subsection{Magnitude effects of undervaluation}

Having found evidence in favor of real undervaluation, the question arises about the magnitude of RER misalignment and its impact on growth. In order to test for sensitivity to different "undervaluation" levels, we run regressions for the three $k$-means clusters of undervaluation presented in Table 4, two of which correspond to real undervaluation levels, and the other groups to the overvalued cases. Nonetheless, it should be noted that, as influential observations were removed from the sample, we do not test for the effects of large values of the undervaluation index ${ }^{10}$.

Table 9 presents the estimations results for the full sample and for the subsets of industrial and non-industrial countries. Interestingly, the undervaluation index is not significant in any of the three clusters for developed economies, whereas for non-industrial countries only a real undervaluation of about $26 \%$ (on average) has a significant and positive impact on growth (see table 4). In turn, high undervaluation and overvaluation are not found relevant to explain economic performance. An intuition for this result is that there could be decreasing returns in the undervaluation levels: the more devaluated the real exchange rate, the less impact a further devaluation will have over economic growth.

\subsection{Control variables}

In this section, we carry out the empirical study on the economic growthRER relationship introducing the control variables aforementioned. Table 10 reports the results of the estimation of the complete model in subsample of nonindustrial countries with undervalued RER, where the undervaluation index was found significant to explain growth (Table 9, Column 9). The standard control variables are added to the baseline equation one by one to avoid multicollinearity. The long-run effect of undervaluation is robust to the inclusion of almost all the control variables. In fact, only except for the gross domestic savings (Savings), the undervaluation index is significant and has the expected (positive) sign. This variable is nearly linked to the level of investment, which is found to be a very robust and significant determinant of economic growth (Levine and Renelt, 1992). The intuition is that the level of savings is already capturing the potential effects of other explanatory variables of economic growth, in particular the level of real exchange rate. Hence, in general the evidence on the effects of an undervalued RER on the economic performance of non-industrial countries is robust to the inclusion of control variables.

10 While the literature excludes values of the undervaluation index higher than 1.5 (in absolute terms), we proceeded by removing the influential values after regressing growth on the undervaluation index. This allows us to have a clearer sample, as we removed observations with a high value in the independent variable only when they are influential in the sense that those observations also affect growth. 


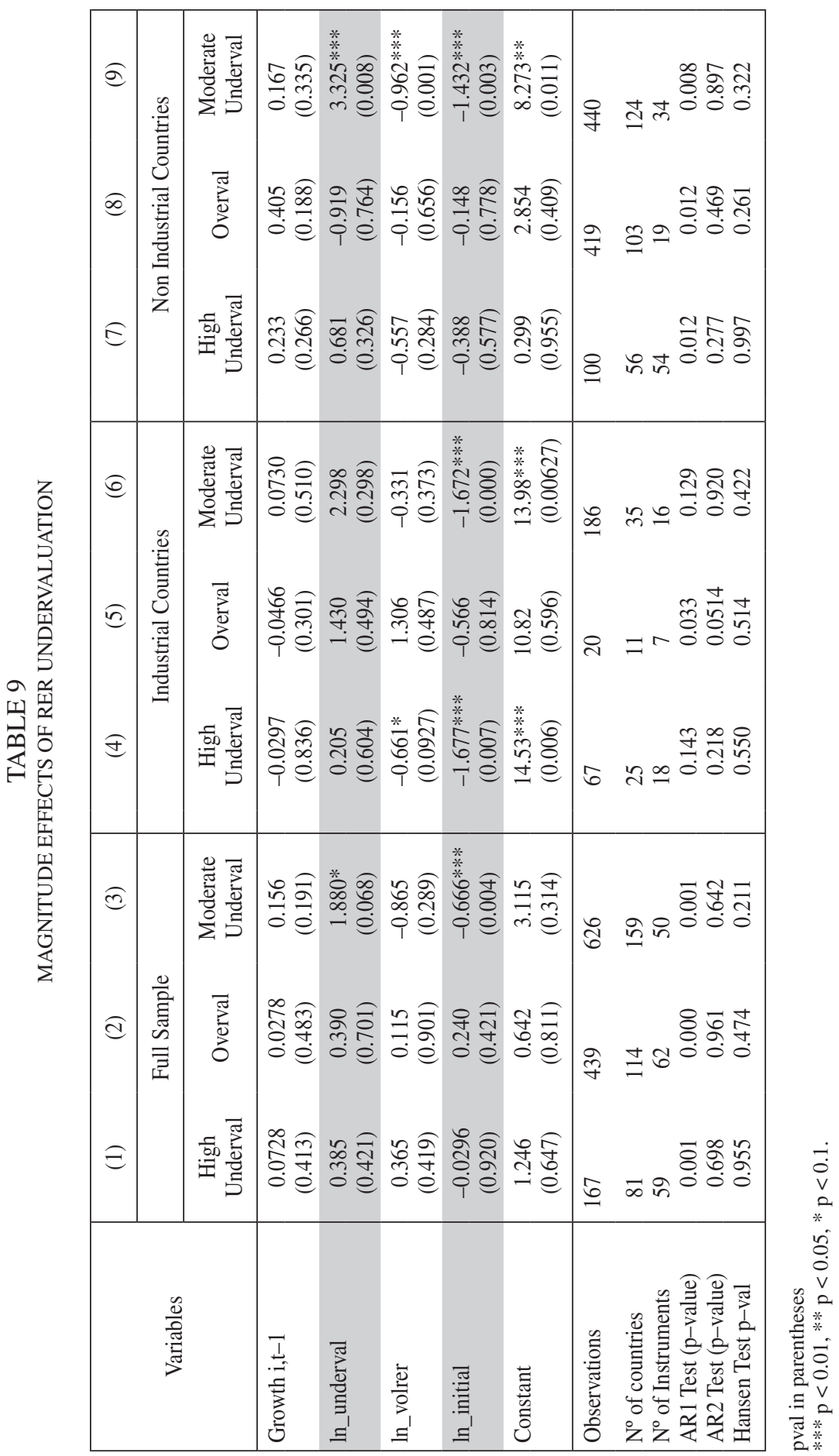


TABLE 10

NON-INDUSTRIAL COUNTRIES WITH UNDERVALUATED RER

\begin{tabular}{|c|c|c|c|c|c|c|}
\hline Variables & Inflation & Gov to GDP & Ext. Debt & Open & TOT & Savings \\
\hline Growth i,t-1 & $\begin{array}{l}0.0108 \\
(0.77)\end{array}$ & $\begin{array}{r}0.0425 \\
(0.374)\end{array}$ & $\begin{array}{c}0.176^{* * *} \\
(0.0033)\end{array}$ & $\begin{array}{c}0.0559^{*} \\
(0.0987)\end{array}$ & $\begin{array}{c}0.107 \\
(0.118)\end{array}$ & $\begin{array}{l}0.207 * * * \\
(0.0029)\end{array}$ \\
\hline ln_underval & $\begin{array}{l}13.26^{* *} \\
(0.0191)\end{array}$ & $\begin{array}{l}11.44 * * \\
(0.0228)\end{array}$ & $\begin{array}{l}4.304 * * * \\
(0.0004)\end{array}$ & $\begin{array}{c}2.989 * * \\
(0.0412)\end{array}$ & $\begin{array}{c}7.091 * * \\
(0.0437)\end{array}$ & $\begin{array}{c}4.198 \\
(0.256)\end{array}$ \\
\hline ln_volrer & $\begin{array}{l}-2.627 * * * \\
(0.0059)\end{array}$ & $\begin{array}{l}-1.987 * * * \\
(0.0018)\end{array}$ & $\begin{array}{l}-1.056^{* * * *} \\
(0.0033)\end{array}$ & $\begin{array}{l}-0.995 * * * \\
(0.0047)\end{array}$ & $\begin{array}{c}-1.481 * * * \\
(0.0041)\end{array}$ & $\begin{array}{c}-1.172 * * \\
(0.0214)\end{array}$ \\
\hline ln_linfla & $\begin{array}{c}-0.0895 \\
(0.782)\end{array}$ & & & & & \\
\hline ln_initialper & $\begin{array}{c}-3.348^{* *} \\
(0.0105)\end{array}$ & $\begin{array}{l}-2.667 * * * \\
(0.005)\end{array}$ & $\begin{array}{c}-1.401^{* * *} \\
(0.0015)\end{array}$ & $\begin{array}{c}-1.658^{* * *} \\
(0.0001)\end{array}$ & $\begin{array}{c}-2.558^{* *} \\
(0.0155)\end{array}$ & $\begin{array}{c}-1.731 * * \\
(0.0277)\end{array}$ \\
\hline gov_gdp & & $\begin{array}{c}0.0148 \\
(0.893)\end{array}$ & & & & \\
\hline ln_extdebt & & & $\begin{array}{l}0.07 \\
(0.872)\end{array}$ & & & \\
\hline ln_open & & & & $\begin{array}{r}1.346 * * * \\
(0.00994)\end{array}$ & & \\
\hline ln_tot & & & & & $\begin{array}{l}-1.03 \\
(0.544)\end{array}$ & \\
\hline savings & & & & & & $\begin{array}{c}0.0131 \\
(0.362)\end{array}$ \\
\hline Constant & $\begin{array}{l}13.52 * * * \\
(0.00629)\end{array}$ & $\begin{array}{l}9.766 * * * \\
(0.0030)\end{array}$ & $\begin{array}{c}7.821^{* *} \\
(0.0155)\end{array}$ & $\begin{array}{c}6.011^{* *} \\
(0.0159)\end{array}$ & $\begin{array}{c}14.74 * * * \\
(0.0002)\end{array}$ & $\begin{array}{l}10.20^{* * * *} \\
(0.0034)\end{array}$ \\
\hline Observations & 322 & 383 & 271 & 401 & 249 & 378 \\
\hline $\mathrm{N}^{0}$ of countries & 99 & 111 & 93 & 117 & 84 & 111 \\
\hline $\mathrm{N}^{\circ}$ of Instruments & 35 & 35 & 35 & 35 & 35 & 35 \\
\hline AR1 Test (p-value) & 0.0053 & 0.0033 & 0.0023 & 0.0004 & 0.0001 & 0.0004 \\
\hline AR2 Test (p-value) & 0.602 & 0.607 & 0.766 & 0.831 & 0.315 & 0.933 \\
\hline Hansen Test (p-value) & 0.135 & 0.377 & 0.831 & 0.117 & 0.194 & 0.331 \\
\hline
\end{tabular}

pval in parentheses.

$* * * \mathrm{p}<0.01, * * \mathrm{p}<0.05, * \mathrm{p}<0.1$.

\section{Concluding Remarks}

This paper explores the economic growth-RER relationship in a wide sample of countries. In order to avoid the influence of aberrant observations on the estimations, outliers detected in the database by means of Cook's Distance were excluded from the sample. In first place, the evidence shows that RER undervaluation is positively associated with income level. In fact, higher income countries show a more depreciated RER. In second place, the estimations carried out with the baseline model show that in general undervaluation affects positively and RER volatility affects negatively economic growth in developing 
countries throughout two different classifications: by the current development status (industrial and non-industrial countries) and by income levels defined in a dynamic way.

The third result refers to the asymmetric effects of the RER misalignment. A positive coefficient of the undervaluation index could be picking up two alternative links to growth: a negative link with overvaluation or a positive one with undervaluation. In order to discard the first possibility, we split the sample by their undervaluation index and estimated the model in each possible scenario (over- and undervaluation), which confirmed our first findings: a real undervaluation has a positive effect on growth.

The last result refers to the magnitude effect of undervaluation. Using the k-means algorithm, we divided the sample into three clusters according to the undervaluation index, and estimated the benchmark model for each one. The results were quite surprising. While the literature alleges that a higher and competitive RER is beneficial for growth, we found that the "high undervaluation" and the overvaluation clusters are not statistically significant, while within the cluster of a moderate level of undervaluation (a $26 \%$ on average), the impact on growth was positive and significant for non-industrial countries. This result could be reflecting possible decreasing returns in the undervaluation levels: the more devaluated the real exchange rate, the less impact a further devaluation will have over economic growth.

Finally, the results are in general robust to the inclusion of the standard control variables in non-industrial countries.

In short, similarly to Rapetti (2012) our evidence shows that in developing countries, an undervalued RER positively affects economic growth, while RER volatility seems to be harmful. However, it is worthwhile noting that "too much" of an undervaluation could mean no gains in terms of long term performance, while an undervalued RER that is not far from its equilibrium value is found significant and positive to explain economic growth.

In terms of economic policy recommendations, our evidence partially supports the export-led growth hypothesis, as it suggests that only a slightly depreciated real exchange rate (about $26 \%$ over the "equilibrium RER") is beneficial for growth. However, large devaluations -those that were excluded because of their outlying values- are probably harmful to long-term growth, because of the social and economic costs associated to them. Further research is required to help refine the analysis of the impact of exchange rate policies on growth and development.

\section{REFERENCES}

Abida, Z. (2011). "Real exchange rate misalignment and economic growth: an empirical study for Maghreb countries", International Journal of Economics and Finance, Vol. 3; 190-201.

Aguirre, A. and C. Calderón (2005). "Real exchange rate misalignments and economic performance," Central Bank of Chile, Working Paper 315.

Baltagi, B. (2014). "The Oxford Handbook of Panel Data", OUP Catalogue, Oxford University Press.

Benhima, K. (2012). "Exchange rate volatility and productivity growth: the role of liability dollarization”, Open Economic Review, Vol. 23; 501-529. 
Berg, A. and Y. Miao (2010). "The Real Exchange Rate and Growth Revisited: The Washington Consensus Strikes Back?, IMF Working Papers 10/58 (Washington: International Monetary Fund).

Bleaney, M. and D. Greenaway (2001). "The impact of terms of trade and real exchange rate volatility on investment and growth in sub-Saharan Africa", Journal of Development Economics, Vol. 65; 491-500.

Calinski, T. Harabasz, J. (1974). "A Dendrite Method for Cluster Analysis", Communications in Statistics - Theory and Methods, Vol. 3 (1); 1-27.

Cottani, J., D. Cavallo and K. Shahbaz (1990). "Real exchange rate behavior and economic performance in LDCs", Economic Development and Cultural Change, Vol. 39; 61-76.

De Vita, G. and K. Kyaw (2011). "Does the choice of exchange rate regime affect the economic growth of developing countries?", The Journal of Developing Areas, Vol. 45; 135-153.

Díaz Alejandro, C. (1963). "A note on the impact of Devaluation and the Redistributive Effect", Journal of Political Economy, Vol. 71; 6.

Easterly, W. (2005). "National policies and economic growth", in Philippe Aghion and Steven Durlauf, editors, Handbook of Economic Growth, Elsevier.

Elbadawi, I., L. Kaltani and R. Soto (2012). "Aid, rear Exchange rate misalignment, and economic growth in sub-Saharan Africa", World Development, Vol. 40; 681,700.

Eichengreen, B. (2008). "The real exchange rate and economic growth", Social and Economic Studies, Vol. 56; 7-20.

Fischer, S. (1993). "The role of macroeconomic factors in growth", Journal of Monetary Economics, Vol. 32; 485-512.

Gala, P. (2008). "Real exchange rate levels and economic development: theoretical analysis and econometric evidence", Cambridge Journal of Economics, Vol. 32; 273-288.

Ghura, D. and T. Grennes (1993). "The real exchange rate and macroeconomic performance in Sub-Saharan Africa", Journal of Development Economics, Vol. 42; 155-174.

Glüzman, P., E. Levy-Yeyati and F. Sturzenegger (2012). "Exchange rate undervaluation and economic growth: Díaz Alejandro (1965) revisited", Economic Letters, Vol. 117; 666-772.

Haddad, M. and Pancaro, C. (2010). "Can real exchange rate undervaluation boost exports and growth in developing countries? Yes, but not for long", Economic Premise, World Bank, N. 20.

Hartigan, J. (1975). "Clustering Algorithms (Probability \& Mathematical Statistics", John Wiley \& Sons Inc.

Hausmann, R., L. Pritchett and D. Rodrik (2005). "Growth accelerations", Journal of Economic Growth, Vol. 10; 303-329.

Janus, T. and D. Riera-Crichton (2015). "Real Exchange Rate Volatility, Economic Growth and the Euro", Journal of Economic Integration, Vol. 30; 148-171.

López and Perrotini (2006). "On floating exchange rates, currency depreciation and effective demand", Banca Nazionale del Lavoro, vol. LIX, 238; 221-42.

Magud, N. and S. Sosa (2010). "When and Why Worry About Real Exchange Rate Appreciation? The Missing Link between Dutch Disease and Growth", IMF Working Paper 10/271 (Washington: International Monetary Fund). 
Rapetti, M., P. Skott and A. Razmi (2012). "The real exchange rate and economic growth: are developing countries different?", International Review of Applied Economics, Vol. 26, 735-753.

Razin, O. and S. Collins (1999). "Real exchange rate misalignments and growth", in The Economics of Globalization: Policy Perspectives from Public Economics, Assaf Razin and Efraim Sadka eds. Cambridge University Press.

Rodrik, D. (2008). "The real exchange rate and economic growth", Brookings Papers on Economic Activity, Vol. 2; 365-412.

Rousseeuw, P. and A. Leroy (2005). "Robust regression and outlier detection", John Wiley \& Sons.

Tang, B. (2015). "Real exchange rate and economic growth in China: A cointegrated VAR approach", China Economic Review, Vol. 34; 293-310.

Tarawalie, A. (2010). "Real exchange rate behavior and economic growth: evidence from Sierra Leone", South African Journal of Economic and Management Sciences, Vol. 13; 8-25.

Vieira, F., M. Holland, M., C. da Silva L. and Bottecchia (2013). "Growth and exchange rate volatility: A panel data analysis", Applied Economics, Vol. 45, 3733-3741.

\section{ApPendix}

\subsection{Appendix 1: Optimal Number Of Clusters}

We use the Calinski and Harabasz (1974) pseudo-F index to determine the optimal number of clusters. Larger values of the index indicate more distinct clustering. Following this criteria, the optimal number of clusters for the undervaluation index is three. Table 11 presents the Calinski index for different numbers of clusters using the k-means clustering algorithm. The partition with the highest index is three.

TABLE 11

DIFFERENT CLUSTERING FOR THE INFLATION RATE DATA

\begin{tabular}{|cc|}
\hline Number of clusters & $\begin{array}{c}\text { Calinski-Harabasz } \\
\text { pseudo-F index }\end{array}$ \\
\hline 2 & 1928.92 \\
3 & 2118.77 \\
4 & 2025.74 \\
\hline
\end{tabular}

\subsection{Appendix 2: Outlier Detection And Treatment}

As shown in Table 2, there is some evidence of the presence of possible outliers in the sample. The minimum and maximum values of the growth rate data are away from the corresponding limits, while the undervaluation index 
and the RER volatility series have observations that far exceed the "fences" of the Tukey rule. Thus, it becomes crucial to carry on a careful examination of the data, in order to determine whether the extreme observations presented in the data have a significant influence on the estimated parameters of the regressions in Section 3. If that is the case, the second step is deciding what should be done with these observations: they could be removed of the sample, down- weighted in the regressions or "winsorized" to (i.e. replaced by) the nearest quartile, to mention a few procedures. In this sense, the decision will have to be grounded not only on some sound statistical criteria, but also in the nature of the macroeconomic data under analysis ${ }^{11}$.

Selecting the right set of data is a relevant matter for the empirical analysis. As Baltagi (2014) points out, classical estimators such as OLS, generalized least squares, two-stages least squares and GMM have a breakdown point of zero, meaning that a single outlier will cause the orthogonality conditions not to meet (for instance, the present outliers could break down the estimator by making perfectly collinear the explanatory variable and the instruments). Thus, by not dealing with the outliers prior to the estimations could result in spurious relationships, as they are based solely on the inclusion of extreme values.

We run a simple regression of growth on the undervaluation index, which gives a first approach into what could be the influential observations in the dataset. The two-dimensional graphical representation is a rudimentary but helpful tool, as there are no standard procedures for identifying outliers in the context of panel data ${ }^{12}$.

Figure 1 depicts the relationship between real per capita GDP growth and the change in the undervaluation index (in natural logs). Several observations have been flagged with the country and the corresponding five-year period, because they a priori seem to fall into one of the three types of "influential observations" identified in the robust statistics literature: vertical outliers, good or bad leverage points (see Rousseeuw and Leroy, 2005). Vertical outliers are those values that have a large error term (in the y-dimension), but are not outlying in the $\mathrm{x}$-space. In this case, the observation of Malawi '65-'69 could be a vertical outlier (of high growth rate), and analogously Mozambique '70-'74 (of low growth rate). High leverage points are observations that are far from the mean in the x-space; points that have high but "good" leverage are those close to the regression line, while the ones qualified as "bad" are located far away from it. In this case an example of a "good leverage" point might be El Salvador'75-'79, while suspected "bad leverage" points are El Salvador '85-'89, and Norway '70-'74.

11 Unlike survey data, an unusual observation in a macroeconomic variable is more likely to reflect a real phenomenon than to be reflecting a coding error, a misplaced decimal point, etc. This is why the treatment of the outliers does not only depend on the threshold of certain criteria, but also on the criterion of the researcher.

12 As Baltagi (2014) points out: "Although there is a huge literature about robust statistics spanning 60 years, there are but a few papers that we know of in the context of panel data econometrics" (pág. 419). The author mentions the works of Bramati and Croux (2007), and Croux and Verardi (2008) about robust estimation in linear static panel data models, and Lucas et al. (2007) and Baltagi and Bresson (2012) about dynamic panel data methods. However, the lack of a well-coded procedure in the available software makes it still difficult to apply the proposed changes in the estimations to large panel datasets. 
FIGURE 1

ECONOMIC GROWTH AND UNDERVALUATION - FULL WORLD SAMPLE

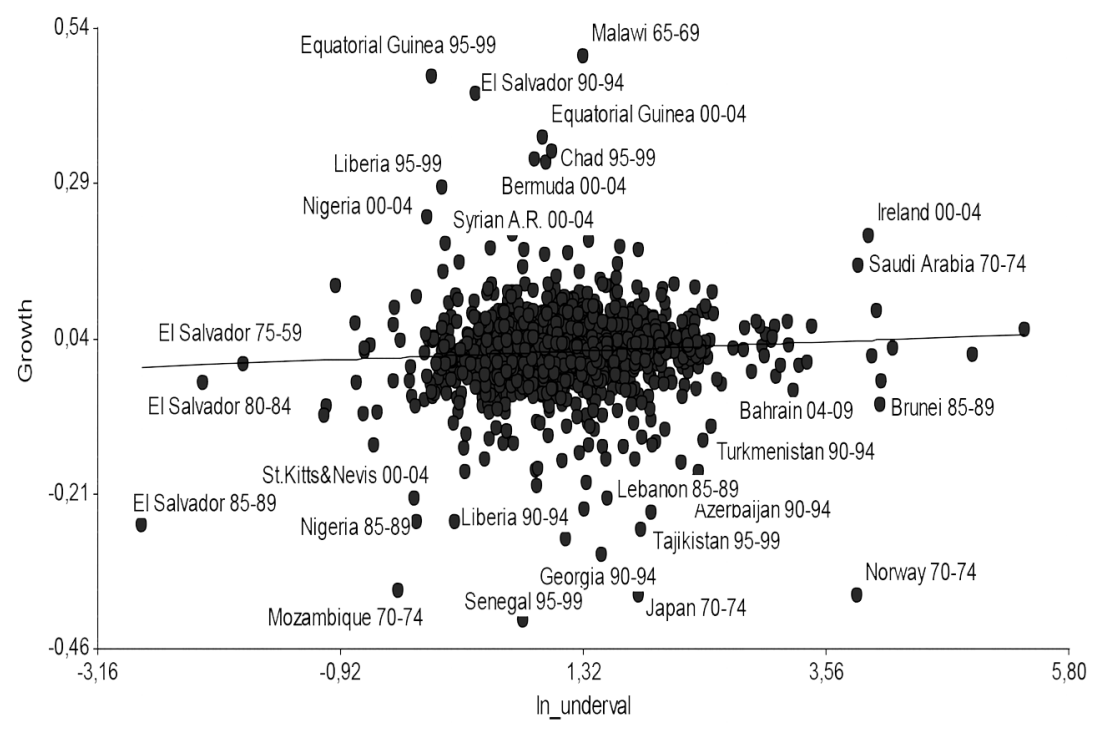

However, not all these cases are "influential observations", in the sense that their exclusion from the dataset will significantly change the slope and/or the intercept of the estimated parameters. "Influence" refers specifically to the proniluct of discrepancy in $\hat{Y}$ (outliers) and high leverage (extreme observations in $\hat{X}$ ), and it is usually measured using Cook's distance.

In Figure 2 the distribution of the studentized residuals versus the fitted values of a simple regression indicates the presence of outliers, that is, observations with unusually high or low economic growth. Certain periods of Malawi, El Salvador, Chad, Bermuda and other countries, which were marked as candidates in Figure 1, are now detected as outliers.

Figure 3 plots the leverage of the observations in the sample. As a rule of thumb, leverage values greater than twice the mean leverage value are considered outlying observations in the X-space. In this case, as the mean leverage is 0.0014 , the critical value is 0.0028 .

Finally, Figure 4 combines the information in the two previous graphs. The influential observations are those exceeding the critical value of Cook's Distance obtained by calculating $4 / \mathrm{n}$, where $n$ is the number of observations. In this case, the critical value is 0.0024 . This analysis shows that even after both the growth rate and the undervaluation index have been transformed by taking their natural logarithms, Cook's distance of some observations remain quite above the critical value ${ }^{13}$. This means that the inclusion of more regressors and the use

13 Only the undervaluation index is scrutinized for outlier detection because the RER volatility behaves in a similar way, because both variables are calculated by using the RER as a base. Moreover, the RER is calculated as the inverse of the price level of GDP (base 
FIGURE 2

RESIDUALS VERSUS FITTED VALUES

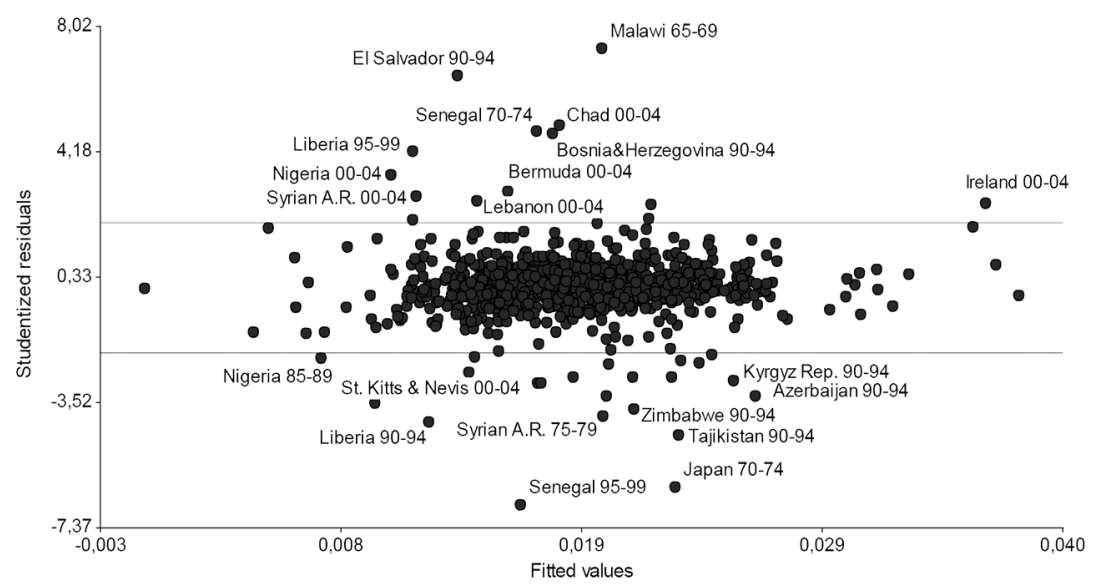

FIGURE 3

LEVERAGE (OR HAT VALUES)

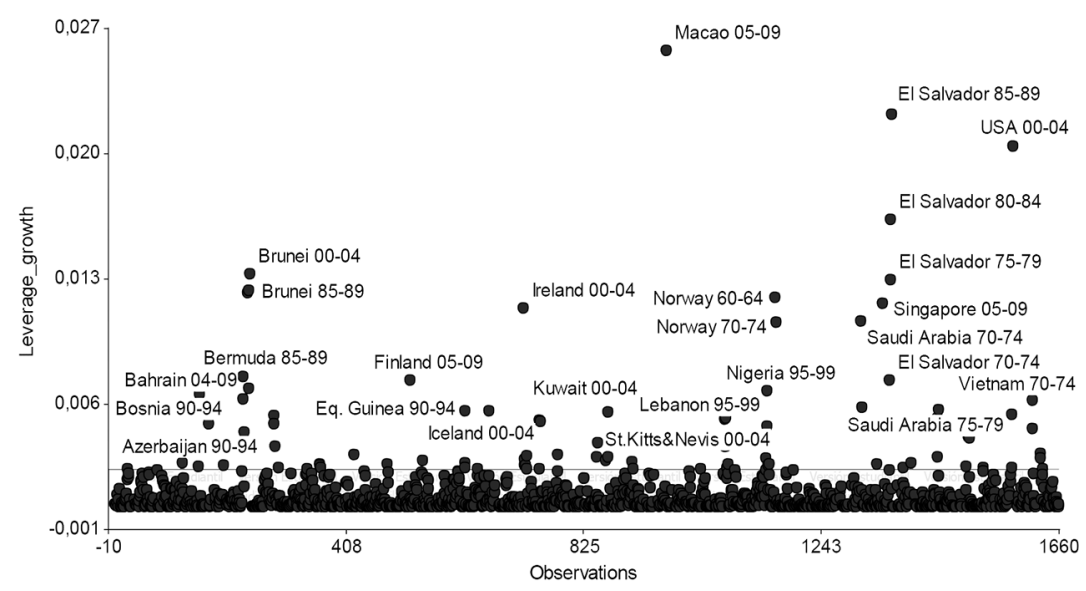

2005). Whenever there is a slight deflation -with a relatively constant nominal exchange rate- the RER takes negative values. When taking natural logarithms of the variable, this phenomenon disappears, but still gives an insight of the RER behavior. 


\section{FIGURE 4}

COOK'S DISTANCE

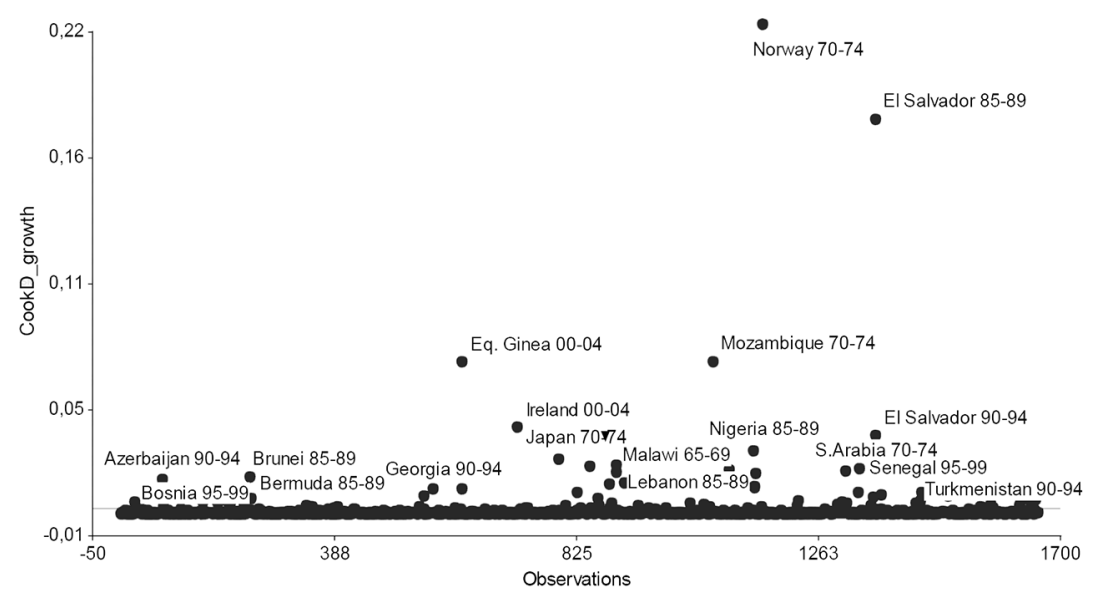

of other estimation methods might give different results in terms of influential point, but still there are some observations that clearly need to be excluded from the sample in order to avoid spurious regressions. In this sense, in Table 12 we replicate the results in Table 9 including the outliers in the regressions, i.e., using the complete sample.

Although the main result seems to be the same with and without outliers -this is, the "moderate undervaluation" cluster is significant to explain growth in non-industrial countries- another result shows up in this regression: the "overvaluation" cluster becomes significant in the same country group. However, not only is this regression spurious because of the inclusion of outliers, but also the interpretation of the clusters is affected: when grouping all the observations, the resulting clusters have a higher mean and standard deviation with respect to the "non-outliers" clusters. This also leads to a different interpretation of the clusters' impact on economic growth. 


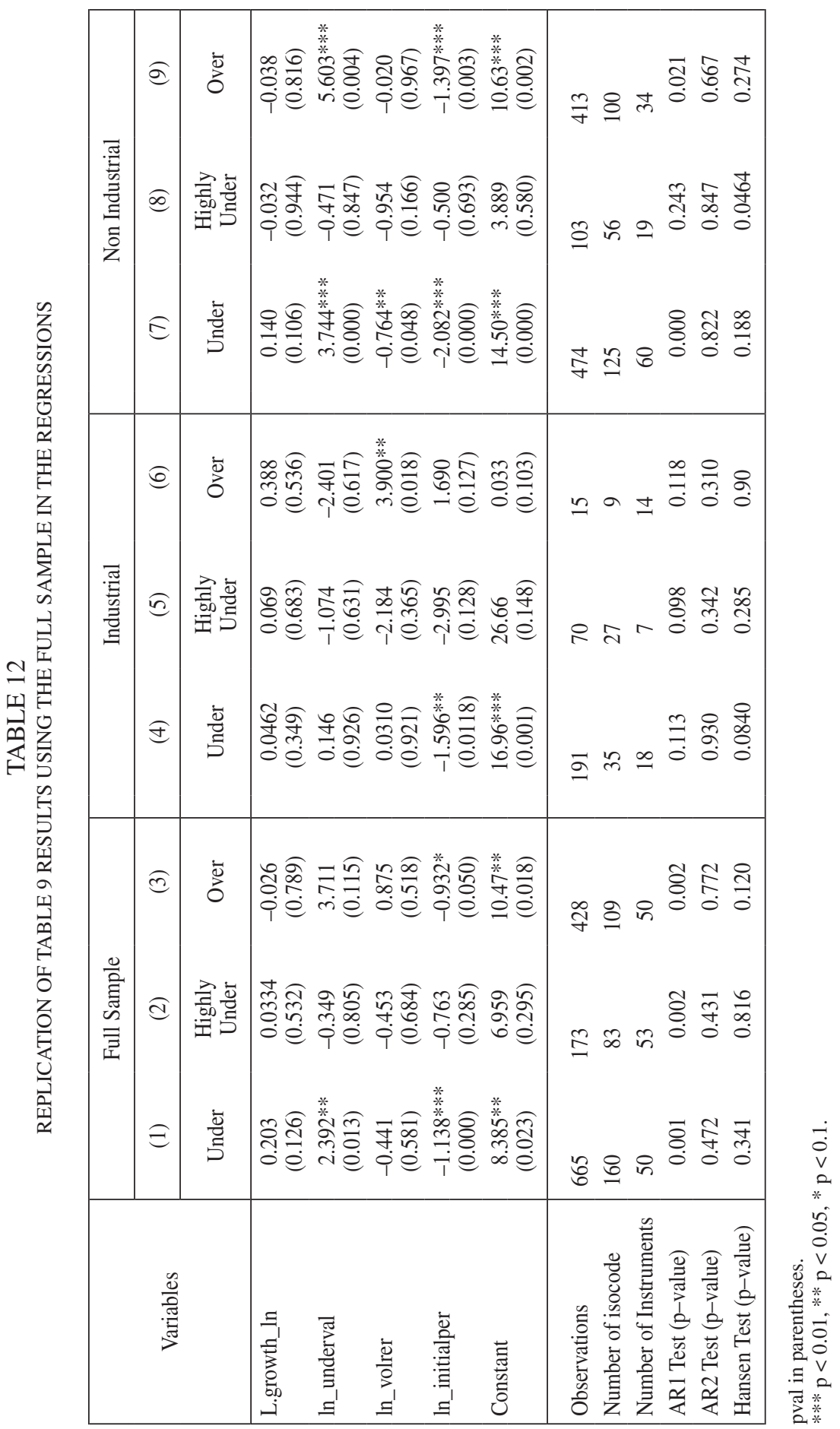

